\title{
Role of China in Rohingya Crisis
}

\author{
Mushfek-Ul- Alam ${ }^{1}$ \\ ${ }^{1}$ Researcher, Bangladesh University of Professionals (BUP), Dhaka, Bangladesh \\ Correspondence: Mushfek-Ul- Alam, Researcher, Bangladesh University of Professionals (BUP), Dhaka, \\ Bangladesh.
}

Received: October 25, 2021

doi:10.5539/ibr.v15n1p59
Accepted: November 18, 2021

Online Published: December 7, 2021

URL: https://doi.org/10.5539/ibr.v15n1p59

\begin{abstract}
The research paper focuses on investigating geo-political moves from the Chinese perspective whether there is a possibility for China to succeed in their negotiating acts between Bangladesh and Myanmar, which chronologically provides: a background to find the origin of the problem, clarifies reasons so important as a negotiator in this issue, the possible outcomes of the negotiation process and how it may affect China's political standing with a series of research questions and problem statement. The researcher primarily denounces the conventional ideas that China only prefers to look after Myanmar's interest or Sino-Myanmar relationship. Methodology section briefly analyzes the nature of the research and the type of data are used to justify researcher's alternative views. The researcher demonstrates a comparative picture between Bangladesh and Myanmar in terms of their economic, political and military relationship with China both nations equally from their geo-political standing. Finally, the researcher describes to predict the possible outcomes of the current negotiation process considering Chinese involvement in Humanitarian aspects, steps taken by the Myanmar Military regime in repatriating the Rohingyas, Why does the democratic reform process so necessary for China as a negotiator, What Myanmar must do to regain the trust Rohingya citizens and how the current situation is endangering the Chinese diplomacy or why a worsening scenario between China and Myanmar may arise. All the findings and analysis inherently support the author's alternative view and duly answer the research questions. Finally, the researcher discussed about the common lessons learned so far from international relations perspective.
\end{abstract}

Keywords: Rohingya, geo-political, humanitarian, military, regime, inherently

\section{Abbreviations:}

$\mathrm{BBC}$

BRI

BUP

DW

SPSS

UNDP

$\mathrm{UN}$

U.S.

\author{
British Broadcasting Channel \\ Belt and Road Initiative \\ Bangladesh University of Professionals \\ Deutsche Welle \\ Statistical Package for the Social Sciences \\ United Nations Development Program \\ United Nations \\ United States
}

\section{Introduction}

In order to understand the role of China may or may not resolve the Rohingya crisis it is essential to look at the background of the Rohingya history. It is needless to say that both China and Bangladesh are deeply involved in a crisis which is completely Myanmar's domestic problem from the outer perspective. Based on the information captured by Rahman, Anusara, Chanthamith, Hossain and Al-amin (2018) Rohingyas are the ancient settlers of the Arakan state - a state which was lately known as Rakhine where the early dynasties were originated as followers of Hindus and Mahayana Buddhists. This literature further suggests that the Arab traders used Arakan for naval routes, who eventually settled down in Arakan, married members of the local community - as a result the Muslim population grew formidably in the region (Ibid, 2018). Ibid (2018) also prescribed a series of events from which it seems clear that these Muslim communities in Arakan who gradually came to be known as 
Rohingyas, went through many racial conflicts since the Mughal administration that continued up to the post-British colonial period. The above document also provides the researcher a strong indication that the struggle of the Rohingya population in regard to their ethnic identity is clearly a case of racial discrimination. Majumder, Chopra and Chakraborty (2015) supported this view by describing the Rohingyas as stateless people that existed in Myanmar without being granted a right to citizenship - who are being victimized largely in the Northern part of Myanmar. Even though Islam (2009) defined Rohingyas as Arab traders who guarded around the coastal line of Bay of Bengal and mentioned a common connection between the language of Rohingyas with that of the local community in Chittagong-this notion can also be backed by evidences which are provided by other authors such as Leider (2013) who clearly suggested a crucial link between the Rohingyas and the ancient Bengali Muslims.

The Initial investigation which is conducted by the author convincingly suggests that because of the late incidences which are arising between the Myanmar military and the Arakan Rohingya Salvation Army caused almost 13, 00,000 Rohingyas fleeing from Myanmar to Bangladesh. Circumstantial evidences proved that this above event is imposing a huge economic/environmental/infrastructural burden upon the host community as well as causing numerous number of global and domestic political headaches for the current Bangladeshi government (Imran and Mian, 2014; UNDP, 2018) Third, there are strong evidences to believe that China's path to regional hegemony exerts a maximum effort on not pushing Myanmar or other South-East Asian countries closer to a US or Western dominance in terms of a trade or political rivalries in the region, especially when one considers the persistent US threat to erode the Chinese leadership containment (Yhome, 2019; Joy, 2018; Womack 2004 \& Cheng 2013). Besides, China has many sensitive geo-political issues which linked them to both Bangladesh and Myanmar (Joy, 2018, Yhome, 2018, Ramchandran, 2017 \& Bhattacharjee, 2018). Based on these facts and considering the political, economic as well as military aspects the author predicts that China is bound to simultaneously protect the interests of both Bangladesh and Myanmar despite their so-called preferences in protecting their internal ties with the Myanmar military administration.

\section{Discussion}

Chinese Foreign Minister Wang Yi has wrapped up a visit to Myanmar in which he met his counterpart and de facto leader Aung San Suu Kyi. It was the first visit by a foreign official since the new government took office. What statement is intended with this visit, and what can be expected from the China-Myanmar relationship going forward? Suu Kyi will likely be appointed to a role similar to prime minister, although the bill was opposed by the country's remaining military powers. What should her priorities be? And will a strong relationship with China help her in the formidable tasks of stabilizing the country and boosting economic growth?

China is a permanent member of the UN Security Council with veto power over whether the issue will be brought before the International Criminal Court. It has been reticent about condemning Myanmar's government during the crisis. Hua said China believes the Rohingya issue has a complex historical, religious and ethnic background and China wishes to play a "constructive role" in finding a proper solution. More than 700,000 Rohingya have fled into neighboring Bangladesh over the past year to escape a Myanmar government crackdown that followed rebel attacks on security and police posts. Hua also criticized comments made by President Donald Trump accusing Beijing of not being supportive in efforts to denuclearize North Korea. A textbook case of ethnic cleansing says the UN"s top human rights official. Nearly 400,000 Rohingyas have fled Burma in the past fortnight for neighboring Bangladesh after skirmishes between local militants and authorities triggered a fierce backlash. So what should the wider international community do? China has proposed a three-phase approach to solving the Rohingya refugee crisis involving Myanmar and Bangladesh. Visiting Chinese Foreign Minister Wang Yi outlined China's position at a news conference with Myanmar's State Counselor and Foreign Minister Aung San Suu Kyi on Sunday. The United Nations says more than 480 thousand Rohingya refugees entered Bangladesh in the past month, after fleeing violence in Myanmar. UN Secretary General Antonio Guterres is to address the Security Council on Thursday. The Myanmar government, military and local ethnic Rakhine Buddhists are methodically reshaping the scarred Myanmar state in their absence with any hope of significant numbers of refugee repatriation looking increasingly unlikely; Nowhere is this truer than in Myanmar, where China is a key factor in the peace process and has come to the defense of the government over the Rohingya crisis in Rakhine State. Assessing China's role in and perspectives toward Myanmar's internal conflicts can offer important insights into conflict dynamics inside the country and help for potential U.S. peace support policies. Secretary-General Antonio Guterres Speaks at UN Briefing.

\section{Conclusion}

If Myanmar fails to resolve their internal political conflicts with the ethnic groups, it will bitterly affect the 
Sino-Myanmar relationship in the long-run, therefore, will not only pose challenges for the Chinese political standing in South-East Asia but will also change their current role as a negotiator in the Rohingya issues.

\section{Conflict of Interest}

There was no conflict of interest with or involvement in any organization or entity with any financial or non-financial interest in the title matter or materials discussed in the review article.

\section{Hypothesis}

A. Conventional Wisdom: 'China prefers Myanmar over Bangladesh considering their greater geo-political interests which will affect their role as a mediator in resolving the Rohingya crises in a negative manner'

B. Alternative Wisdom: 'China has an equal geo-political interest in both Bangladesh and Myanmar; China's relationship with Myanmar will certainly experience a diplomatic breakdown, which will affect their role in Rohingya issues given Myanmar fails to resolve their internal political uncertainties in the long run'

\section{Objective of the Study}

To predict the future geo-political direction includes political, economic and defensive position of China in the Rohingya crisis issue as a hegemonic a leader.

\section{Methods}

It was a descriptive study where quantitative and qualitative both type of data was used systematically and accurately. The facts and the characteristics of a given population or an area of interest, individual group or situations in order to find a new meaning, also describe or observe the document aspects, answer questions based on current events. At least five original documents such as Foreign Policy statements made by the President/Prime Minister/Foreign Minister/Defense Minister/Permanent Representative to the United Nations or any official policy paper on Rohingya Issue along with a list of at least 15 journal articles/book chapters/study reports/newspaper commentaries that clearly address the research/term paper topic.6.0. proper ethical consent was taken from the respective concerns. Data was analyzed using computer and SPSS software. As primary documents a list of at least five original documents such-Foreign Policy statements made by the President/Prime Minister/Foreign Minister/Defense Minister/Permanent Representative to the United Nations or any official policy paper on Rohingya Issue and Secondary documents were a list of at least 15 journal articles/book chapters/study reports/newspaper commentaries etc. that clearly address the research/term paper topic.

\section{Qualitative Findings}

Looking at the primary document China proposed a three step plan as a mediator to sort out the relationship between Myanmar and Bangladesh -(1) Ceasefire to restore peace for homeless refugees, (2) Building stronger communication channel between the two countries in order to build a friendly relationship (3) Achieving a sustainable solution to the problem on the basis of mutual agreement and finally revealing the root causes of the problem so that it can increase the development and economic investment in Rakhine (Ministry of Foreign Affairs, 2017). The researcher explored some further qualitative primary documents: In an interview with DW (Deutsche Welle) it seems pretty clear that the Rohingya refugees are adamant to abandon their homeland on a permanent basis where the interviewee Foreign Minister AK Abdul Momen clearly mentioned about relocating these refugees in Bhasan Char. Statements which are made by the foreign ministry of People's Republic of China indicate the following: "Wang Yi expressed that China was pleased to see the progress made in the process of peaceful reconciliation in Myanmar.

Additionally, document provided by the Chinese Embassy in Bangladesh clearly supports the above data where H.E. Zhang Zuo-the Chinese ambassador repeatedly mentioned in his speech about the 16 billion dollars of bilateral trade, the size and the amount of Chinese engineering contracts in Bangladesh compared to the other countries in South-East Asia and the growing size of the e-commerce and financial market linkages between the two nations. The researcher tried get some collective evidences on Chain's current foreign policy by exploring one of the recent UN speeches given by the Chinese president because the researcher thinks this new Chinese guideline might add a whole new dimension to it's current relationship with the Myanmar military regime in resolving the Rohingya crisis. Consultation is an important form of democracy, and it should also become an important means of exercising contemporary international governance. We should resolve disputes and differences through dialogue and consultation" (UN Speech, 2015)

Additional primary documents were collected which may help in identifying the negative aspects for China in regard to Myanmar's foreign policy on the problem considering the positive ideology of the Chinese president:

In an interview with BBC (British Broadcasting Channel) Myanmar leader Aung San Suu Kyi had shown a 
strong denial of any type of ethnic cleansing (Kyi, 2017) the researcher was willing to instigate a possibility of whether China will be under any kind of circumstantial pressure from the international community due to the predicted failure in it's mediation role and will that be a challenging issue from Chinese diplomatic perspective?

As a part of that investigation, it was revealed that China faces a tremendous pressure from US and it's Western allies in regard to their present views on Rohingya crisis and dealings with Myanmar. So there is a strong reason to believe that the above circumstance may ultimately produce a negative impact on their political standing in South-East Asia. First of all, China was severely criticized for it's current political attitude towards US. (Pence, 2018, p.1). No 'primary quantitative' evidence on the above issues could be collected by the researcher due to the shorter span of time.

\section{Secondary Documents}

Chinese political interest in Mynanmar: From the findings of Yhome (2018) it seems China's political interests in Myanmar arises from the background of the ethnic conflicts in Myanmar - which is strongly linked to its borderland security. The finding also confirmed that "border stability" is very crucial for China as the process includes border inhabitants with multi-cultural identities leading to conflict of ethnic races near the Chinese border (Ibid, 2018). Ibid (2018)

Screening through the above documents, one could clearly arrive at this conclusion that China serves a greater political influence in Myanmar which they could always use to their advantage, specially, while it comes to playing role as a negotiator in resolving a conflict between the ethnic minorities and the central government of Myanmar but the only issue that concerns the researcher in the current study is whether this role will favor or disfavor the Rohingya Muslim refugees.

Chinese Military interest in Myanmar: The same findings also indicate that the major military aspects which tied up these two countries are as follows: (1) To obstacle the defense planning of India; (2) To facilitate the access to Myanmar naval bases so that it can increase Chinese influences over Indian Ocean; (3) To look after the Chinese commercial interest in South-China Sea (Ibid, 1999). After going through these evidences, the researcher thinks, there is a strong reason to believe that China will continue it's military ties with Myanmar irrespective of the Rohingya issues and international condemnation at Myanmar military's because of their recent action in Rakhine.

Chinese political, economic and military interest in Bangladesh: On the contrary, the researcher gathered additional data that shows China is not wholly interested in Myanmar or only prioritizes their position against a possible terrorist attack by the armed ethnic groups at the borderland. China would always want to avoid a direct military clash. The researcher further believes that any possible clash between China and the Myanmar military may disrupt the Chinese BRI plan and China never wants that.

The lion-share of the China's investments in Myanmar are in the power sector (57\%), while oil, gas and other mining make up $18 \%$ of Chinese investment. A typical feature of Chinese companies investing in Myanmar is that they are usually state-owned (Lwin, 2019).

Table 1. Six major projects to monitor by the Chinese in Myanmar in 2019

\begin{tabular}{|l|l|c|}
\hline $\begin{array}{c}\text { SI } \\
\text { No. }\end{array}$ & \multicolumn{1}{|c|}{ Name of Projects } & $\begin{array}{c}\text { (Estimations In US dollars - } \\
\text { billions for 2019) }\end{array}$ \\
\hline 1 & Kayupkhyu Deep Sea Port & 1.3 \\
\hline 2 & Muse-Mandalay Railway Project & 9 \\
\hline 3 & New Yangoon Development Project & 1.5 \\
\hline 4 & $\begin{array}{l}\text { 3 border economic zones (Muse and Chin Shwe Haw in Shan State, and Kan } \\
\text { Pite Tee in Kachin State) }\end{array}$ \\
\hline 5 & Myitsone Hydro-power project & 3.8 \\
\hline 6 & Kayupkhyu-Kunming railway project & 20 \\
\hline & Total & 41.2 \\
\hline
\end{tabular}

Chart 1 


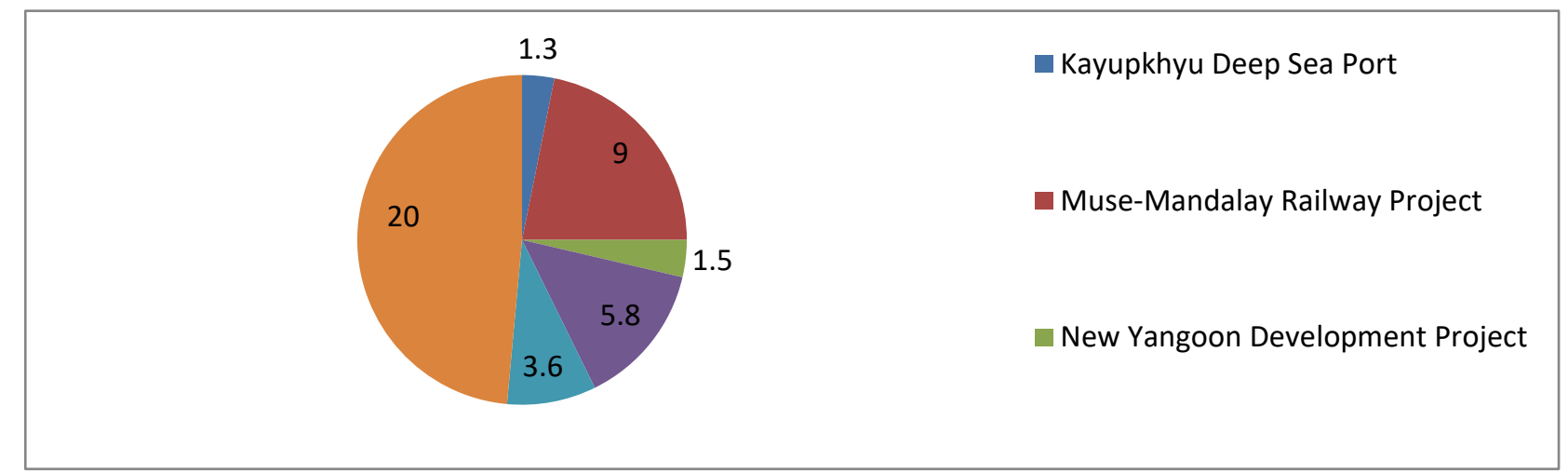

(Lwin, 2019)

\section{Map 1}

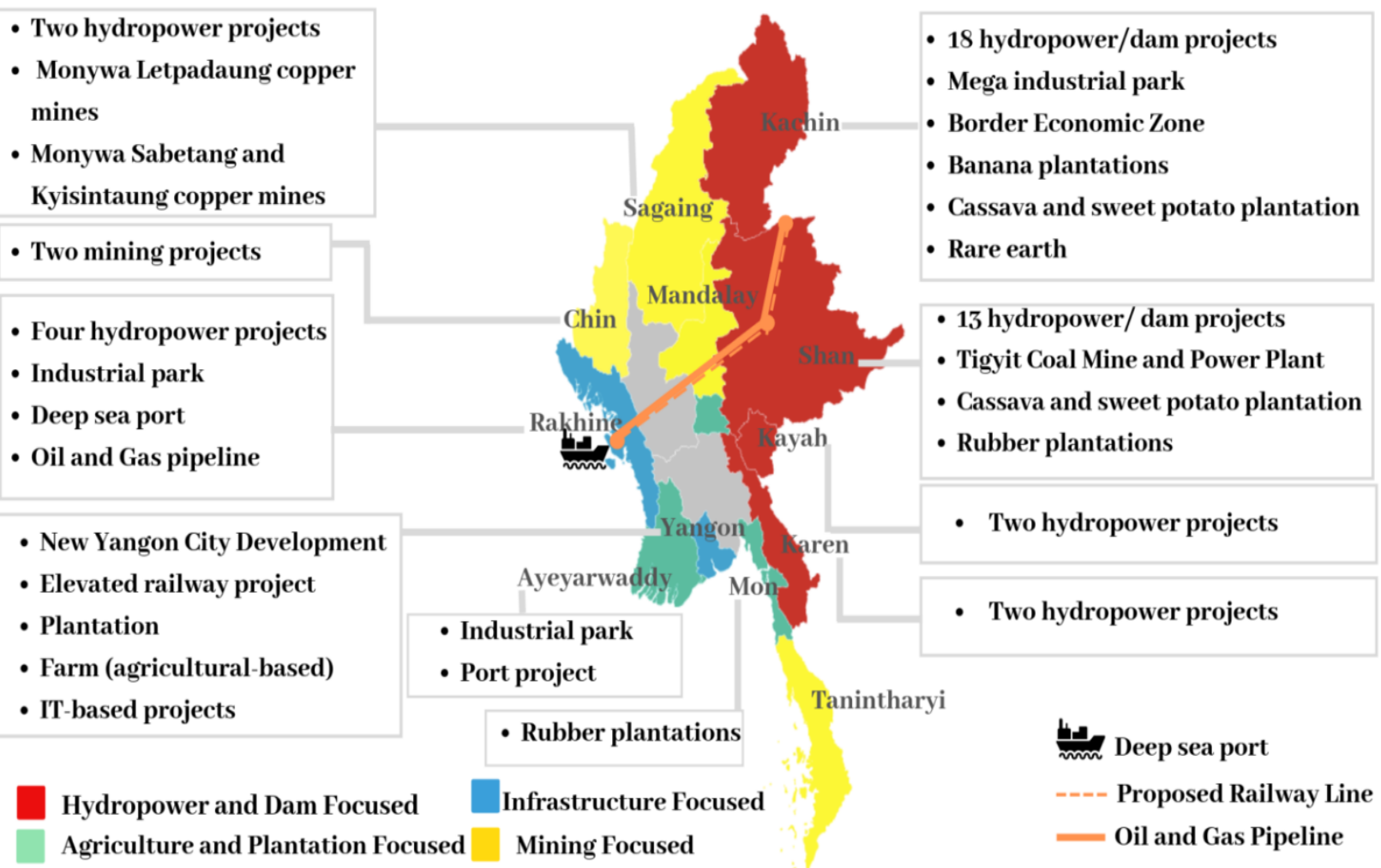

(Lwin, 2019)

\section{Chines Economic Investment in Bangladesh}

Table 2. Chinese Investment in Bangladesh

\begin{tabular}{|l|l|}
\hline Chinese Investment in Bangladesh & (Estimated in US dollars - Billions) \\
\hline FDI & 3.6 \\
\hline Power and Infrastructure related & 21.6 \\
\hline BRI related & 38 \\
\hline Total & 63.2 \\
\hline
\end{tabular}

(Source: Prothom Alo, 2019) 


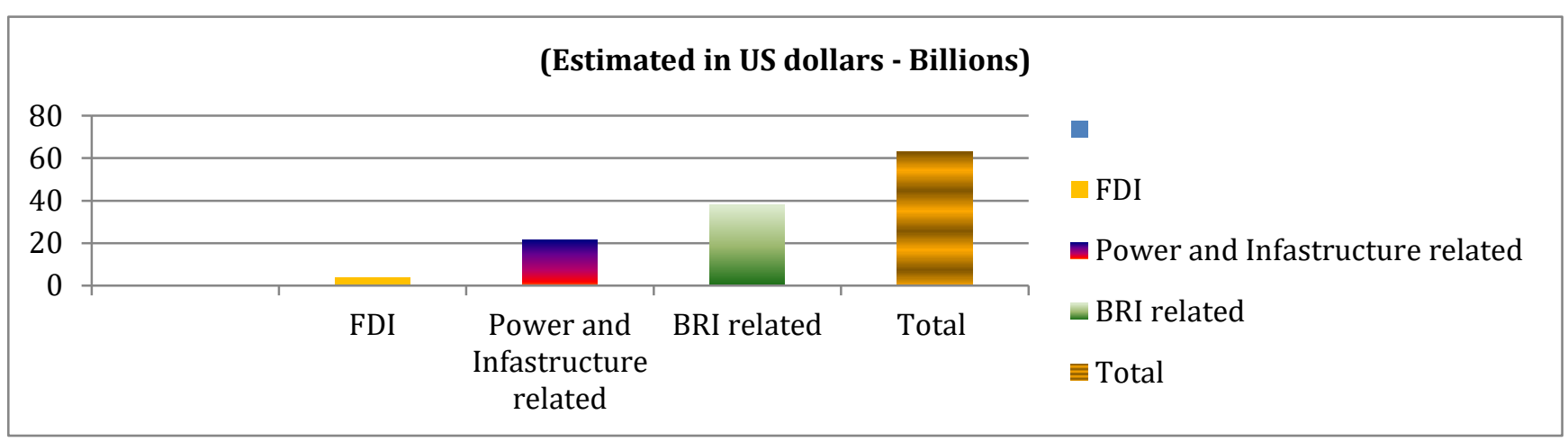

(Source: Prothom Alo, 2019)

\section{Chinese military interest in Myanmar:}

Exchange of high-level visits between Tatmadaw and PLA (People Liberation Army) had significant aspects on military relations through joint training programs where China involved Myanmar officers at the PLA's Staff College and Defense College. China co-operated Burmese army by deploying troops along the border and conducted military exercises in a full scale. China conducted its joint naval exercise with Myanmar since 2017.

\section{Chinese military interest in Myanmar:}

China was the biggest supplier of arms to Bangladesh from 2009 to 2013, with the country accounting for 82\% of the total arms imported by Bangladesh during the period. SIPRI data shows Bangladesh procured anti-ship missiles, tanks, fighter aircrafts and other arms from China between 2008 and 2012 (Dhaka Tribune, 2014; Shao; 2019)

\section{Chart 3}

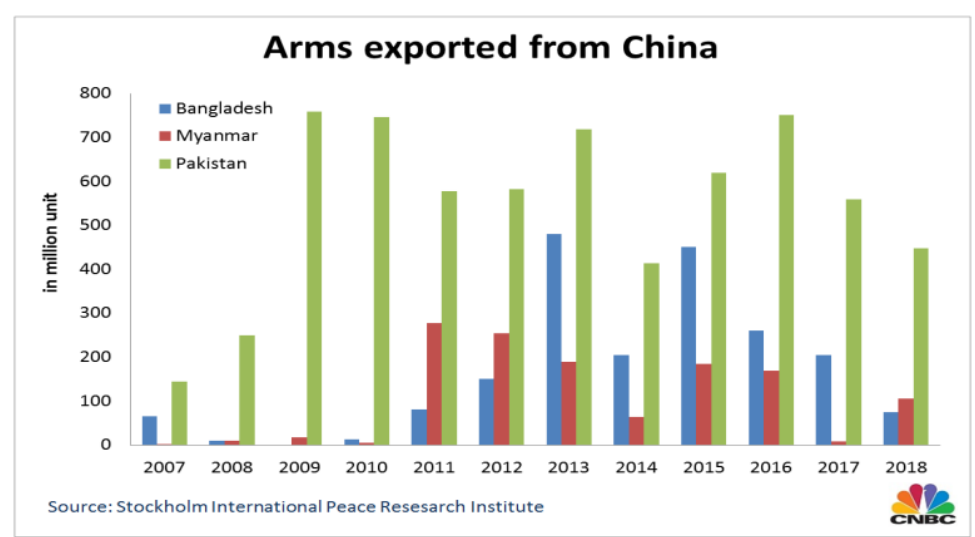

(Source: Stockholm International Peace Research Institute, 2018)

\section{Chinese humanitarian role:}

According to the latest source of information, China will provide 2,500 tons of rice for Rohingyas living in Bangladesh after being forcibly displaced from Myanmar (Times of India, 2019)

Chinese Political interest in Bangladesh and Myanmar:

Not much quantitative data were found in regard to this issue due to the narrative style of the aspect.

Table 1. A. Economic interest-A comparisons of the major Chinese properties

\begin{tabular}{|l|l|l|}
\hline 1 & Current Chinese investment in major projects that concerns Rakhine & 41.2 \\
\hline 2 & Chinese investment in Bangladesh to boost their Belt and Road initiative & 63.2 \\
\hline
\end{tabular}


Chart 4

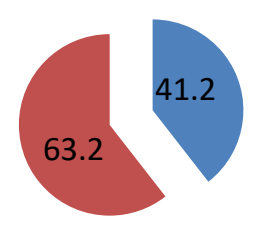

1 Current Chinese investment in major projects that concerns Rakhine

2 Chinese investment in Bangladesh to boost their Belt and Road initiative

(Source: DW, 2019 \& Lwin, 2019)

As the above data clearly suggests (from Table 1. A and Chart 4) that China possesses a greater investment interest based on the recent progression of it's trade relationship with Bangladesh compared to that with Myanmar.

Chart 5

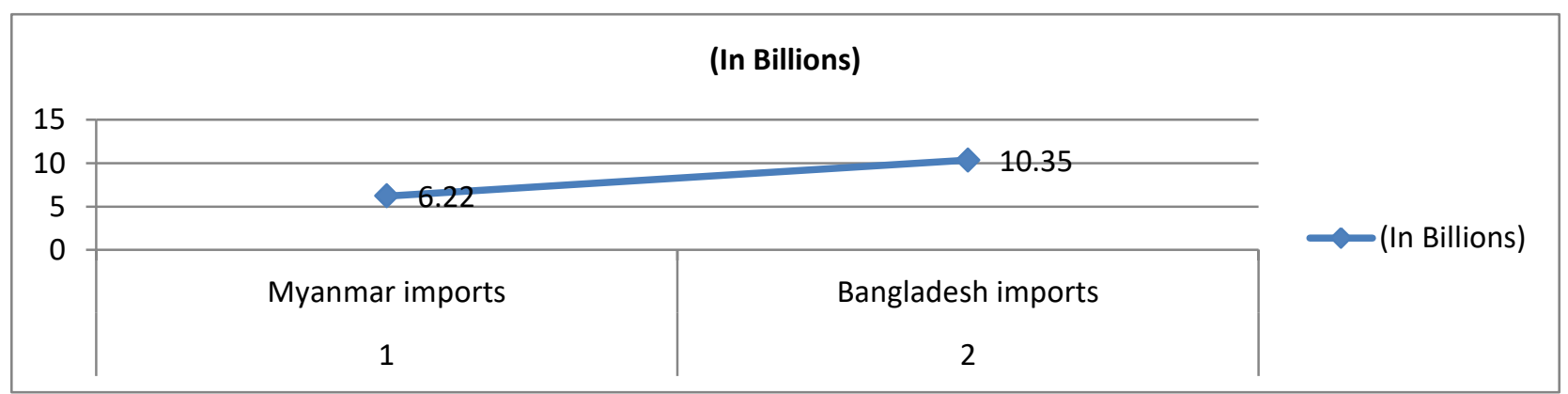

Source: (COMTRADE, 2019)

This above data in Chart 5 strongly supports the earlier claim of the researcher that Bangladesh is currently a more important trade partner with China who recently imported more than Myanmar, therefore, plays a more significant value in terms of the Chinese foreign trade balance.

Table 2. Military interest-A Comparison

Arms export and import from 2014 to 2016

\begin{tabular}{|l|l|l|}
\hline 1 & Bangladesh export of arms and weaponries from China & 890 \\
\hline 2 & Myanmar export of arms and weaponries from China & 440 \\
\hline
\end{tabular}

Chart 6. China's Arms and weaponry investment in both countries - Bangladesh vs. Myanmar

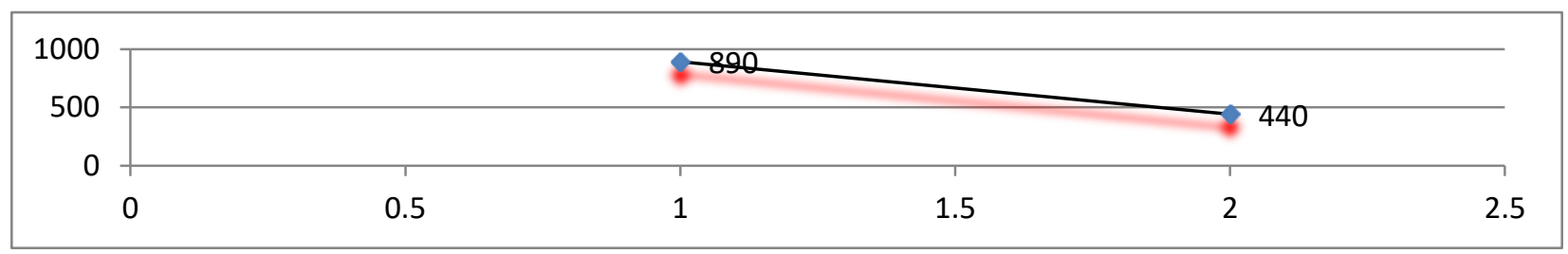

Source: (Dhaka Tribune, 2014; Shao, 2019 \& Perwita, 2018)

Table 1. B and Chart 6 clearly suggest that despite the huge arms supply of China to Myanmar (especially at the crunching time 2014-2016 of the recent Rohingya Crisis), Based on the above data China possess an equal military interest in Bangladesh. So according to the researcher, if anything that is encouraging China to keep it's stronger ties with Myanmar military that is the borderland instability as it might put the Chinese investors in a damaging position in the long run-and it might, in fact adversely affect the Sino-Myanmar relationship. 


\subsection{Qualitative Analysis}

A. From 'Table 1' and 'Chart 1' - the data simultaneously indicate that China has a potential interest in Rakhine.

C. On the other hand, Table 2 and Chart 2 clearly represent the fact that China is strongly interested in protecting their trade interest with Bangladesh;

D. Table 3 further, represents the Chinese interest in building their dominance over South-China Sea which doesn't completely justify the view that China is only interested in addressing the 'Islamic militancy factors' - a problem that is arising due to the armed ethnic wings' in Myanmar.

E. On the contrary, Chart 3 strongly suggests that Bangladesh largely depends on China for their defense capability just as Myanmar or even more. It is good news from Chinese perspective.

F. Going through the primary document on Zuo - the Chinese ambassador's statement during his visit in Bangladesh, it is very much evident that China views Bangladesh as equally important as Myanmar to build it's common market in South-East Asia from economic perspective.

G. The above document also describes information that provides a similarity of the nature of Chinese investment which was made in Rakhine state - purely infrastructural.

After analyzing all these documents there is a strong reason to believe that Chinese motivation is well known and quite familiar - an attempt to build a strong economic region in South Asia that parallelly involves both Myanmar and Bangladesh.

J. Finally, It is also important to remember how China's own human rights violations might play a role in its deliberations. Specifically, China's_treatment of its own Muslim minority is significant.

K. Lantengine and Marc (2015) proposes that China has recently implemented a more multi-dimensional political culture which breeds a strong willingness of maintain a positive approach that might hugely disfavor the Myanmar's current policies about its ongoing attitude towards the domestic problem.

L. it was further evident to the researcher that despite the repeated Chinese diplomatic intervention, neither the invasion of the Myanmar military on ground has stopped nor Myanmar military was being able in succeeding to regain their full control over the armed ethnic groups.

N. Finally, the researcher strongly proposes that Chinese economic, political or military interest in Myanmar are briefly equivalent to those with Bangladesh.

\section{Lessons Learned}

A. China and Myanmar may turn out to be the best friends or the worst foes in the near future due to Myanmar's hardliner approach towards the Rohingya minorities and other internal conflicts.

B. Given China fails to arrive at a positive diplomatic situation - It will create a huge political pressure upon China from the perspective of the international communities.

C. China might have to pay a heavy price by losing it's ties either with Myanmar or Bangladesh in economic, political or military terms but at the same time continuing its support towards the Myanmar military will not bring a positive result for Chinese policy makers.

D. China must prioritize the humanitarian ground over it's national interest. The researcher can be strongly supported by drawing evidences from Song (2018) who believes if China wants to be in a proper leadership role of global refugee governance it must prioritize principles like refugee protection, protect refugees inside their own land and avoidance of coercion which are undoubtedly not happening in case of Rohingya refugees.

\section{References}

Alt, E. J., Calvert, L. R., \& Hums, D. B. (2013). Reputation and Hegemonic Stability: A Game-Theoretic Analysis. American Political Science Review, 82(2), 445-466. Cambridge University press online. https://doi.org/10.2307/1957395

Agnew, J., \& Corbridge, S. (1995). Mastering Space: Hegemony, Territory, and International Political Economy. Routledge, London. Retrieved from http://journals.sagepub.com

Aljazeera. (2017). Letter from a Rohingya: We are facing extinction - A resident of Myanmar's Rakhine State discusses daily life and the abuses and attacks Rohingya endure. Retrieved September 28, 2021, from https://www.aljazeera.com/indepth/features/2017/09/letter-rohingya-facing-extinction-170909113701895.ht 
$\mathrm{ml}$

Aljazeera. (2019). EU extends ban on arms sales to Myanmar over Rohingya crisis- The measures, including embargo on weapons and other equipment, to stay until at least April, 30, 2020. Retrieved September 26, 2021, from

https://www.aljazeera.com/news/2019/04/eu-extends-ban-arms-sales-myanmar-rohingya-crisis-1904300052 24768.html

Bashar, I. (2017). Exploitation of the Rohingya Crisis by Jihadist Groups: Implications for Bangladesh's Internal Security. Counter Terrorist Trends and Analyses, 9(9), 5-7. Retrieved October 24, 2017, from https://www.jstor.org/stable/10.2307/26351550

Bhattacharjee, J. (2018). Decoding China-Bangladesh Relationship; Observer Research Foundation. Retrieved October 3, 2019, from https://www.orfonline.org/expert-speak/41935-decoding-china-bangladesh-relationship/

Byman, D., \& Cliff, R. (1999). China's Arms Sales - Motivation and Implication. RAND; 1700 Main Street, PO. Box 2138, Santa Monica, CA 90407-2138. Retrieved September 30, 1999, from https://www.rand.org/pubs/monograph_reports/MR1119.html

Bhaumik, S. (2017). Why do China, India back Myanmar over the Rohingya crisis? Retrieved October 25, 2017, from

https://www.scmp.com/week-asia/geopolitics/article/2115839/why-do-china-india-back-myanmar-over-rohi ngya-crisis

Char, J. (2016). China-Myanmar Relations since Naypyidaw's Political Transition: How Beijing can Balance Short-Term Interests and Long-Term Values. Retrieved October 2, 2019, from https://www.researchgate.net/publication/305734866_China-Myanmar_Relations_since_Naypyidaw's_Polit ical_Transition_How_Beijing_can_Balance_Short-Term_Interests_and_Long-Term_Values

Charlotte, G. (2017). China Aids Rohingya Refugees in Bangladesh While Backing Myanmar Government; China donates 150 tons of aid to Rohingya refugees in Bangladesh, but doesn't mention the term "Rohingya. Retrieved October 2, 2017, from https://thediplomat.com/2017/10/china-aids-rohingya-refugees-in-bangladesh-while-backing-myanmar-gov ernment/

Cheng, J. (2013). China's Regional Strategy and Challenges in East Asia. Open Edition Journals, 2, 53-65. https://doi.org/10.4000/chinaperspectives.6182

China says it won't block UN action on Rohingya refugees. (2018). YouTube Video; Added by AP Archive [Online]. Retrieved from https://www.youtube.com/watch?v=7tW5nucN5-w

China proposes three-phase solution to Rakhine problem: FM. (2017). You Tube Video; Added by CGTN [Online]. Retrieved from https://www.youtube.com/watch?v=-hKCTD1JHqI

Chinese Interest in Myanmar's Resources Continues | FT World News. (2013). Added by FT world news. Retrieved from https://www.youtube.com/watch?v=YSJ__MurnQ8

China's Role in Myanmar's Internal Conflicts. (2018). You Tube Video; Added by United States Institute of Peace [Online]. Retrieved from https://www.youtube.com/watch?v=Nwgw1xCeP-Q

Daily Star. (2019). China offers Rohingyas money if they return to Myanmar. Retrieved October 6, 2019, from https://www.thedailystar.net/rohingya-crisis/chinese-envoy-offer-rohingya-refugee-6000-dollar-if-they-retur n-myanmar-1711312

Dhaka, T. (2019). UN investigator: US sanctions on Myanmar military leaders inadequate. Retrieved November 1,2019 , from

https://www.dhakatribune.com/world/south-asia/2019/07/19/un-investigator-us-sanctions-on-myanmar-milit ary-leaders-inadequate

DW. (2019). Bangladesh to UN: 'Support Rohingya island relocation or leave the country'. Retrieved September 14,2019 , from https://www.dw.com/en/bangladesh-to-un-support-rohingya-island-relocation-or-leave-the-country/a-50284 651

DW. (2019). Is Bangladesh falling into a Chinese 'debt trap'? Retrieved September 24, 2019, from https://www.dw.com/en/is-bangladesh-falling-into-a-chinese-debt-trap/a-49556829 
Dhaka, T. (2019). China biggest arms supplier to Bangladesh. Retrieved September 25, 2019, from https://www.dhakatribune.com/uncategorized/2014/03/17/china-biggest-arms-supplier-to-bangladesh

Dulock, H. (1993). Research Design - Descriptive Research. https://doi.org/10.1177/104345429301000406

Discussion: China-Myanmar ties (2016). You Tube Video; Added by CGTN [Online]. Retrieved from https://www.youtube.com/watch?v=voOBEV4mOB4

Embassy of People's Republic of China. (2018). Ambassador H.E. Zhang Zuo's Speech at China-Bangladesh relations: Prognosis for the Future. Retrieved October 8, 2018, from http://bd.china-embassy.org/eng/dshd/t1621206.htm

Foreign Ministry of People's Republic of China. (2019). Joint Statement of People's Republic of China and People's Republic of Bangladesh. Beijing. Retrieved from https://www.fmprc.gov.cn/mfa_eng/zxxx_662805/t1679204.shtml

Guardian (2016). Myanmar seeking ethnic cleansing, says UN official as Rohingya flee persecution.

Giblin, B (2013). Economics and Geo-politics - A relationship worth reconsidering. Cairn. Info. Retrieved September 24, 2013, from https://www.cairn-int.info/article-E_HER_151_0003--economy-and-geopolitics-relations-to.htm

Gray, S. C., \& Solan, G. (2008). Why Geopolitics. $24^{\text {th }}$ January [Online]; pp 1-11. https://doi.org/10.1080/01402399908437751

Hudson Institute. (2018). Remarks by Vice President Pence on the Administration's Policy Toward China. Retrieved October 21, 2018, from

https://www.whitehouse.gov/briefings-statements/remarks-vice-president-pence-administrations-policy-tow ard-china/

Human Rights Council. (2018). Report of the Independent Fact Finding Mission on Myanmar; $39^{\text {th }}$ Session, $10-28^{\text {th }}$ September; Agenda Item 4. Retrieved October 18, 2018, from https://www.ohchr.org/Documents/HRBodies/HRCouncil/FFM-Myanmar/A_HRC_39_64.pdf

Han, E. (2017). Geopolitics, Ethnic Conflicts along the Border, and Chinese Foreign Policy Changes toward Myanmar. https://doi.org/10.1080/14799855.2017.1290988

Islam, S., \& Tan, T. H. (2009) A Handbook of Terrorism and Insurgency in Southeast Asia. Edward Elgar Publishing. p. 327; Retrieved September 3, 2009, from

https://www.e-elgar.com/shop/a-handbook-of-terrorism-and-insurgency-in-southeast-asia

Imran, A. F. H., \& Mian, N. M. (2014). The Rohingya Refugees in Bangladesh: A Vulnerable Group in Law and Policy. Journal of Studies in Social Sciences, 8(2), 226-253. Retrieved from https://infinitypress.info/index.php/jsss/article/view/776

Joy, A. (2018). Understanding China's Response to the Rakhine Crisis ; US Institute for peace; 2301 Constitution Ave., NW • Washington, DC $20037 \bullet 202.457 .1700$. Retrieved October 1, 2019, from https://www.usip.org/sites/default/files/2018-02/sr419-understanding-chinas-response-to-the-rakhine-crisis. pdf

Kaung, P. K. (1992). the Danger of Rohingya. Myet Khin Thit Magazine, 25, 87-103.

Ki, W. (2018). Remarks by Wang Yi to the 73rd Session of the United Nations General Assembly. Retrieved October 3, 2018, from https://www.voltairenet.org/article203175.html

Kudo, T., Skidmore, M., \& Wilson, T. (2008). Dictatorship, Disorder and Decline in Myanmar - Myanmar's economic relations with China: who benefits and who pays? pp 87-103; Chapter 4; Retrieved October 14, 2008, from https://www.jstor.org/stable/j.ctt24hf5k.10

Kurecic, P. (2015). Geoeconomic and Geopolitical Conflict. Retrieved September 17, 2015, from https://bib.irb.hr/datoteka/802021.Resource_Conflicts_-_Geopolitical_or_Geoeconomic.pdf

Kamruzzaman. (2019). Myanmar has minimial preparation for Rohingya return. Retrieved October 18, 2019 , from https://www.aa.com.tr/en/asia-pacific/myanmar-has-minimal-prep-for-rohingya-return-report/1540429

Lwin, N. (2019). The Irrawaddy. Retrieved October 6, 2019, from https://www.irrawaddy.com/specials/infographic-30-years-chinese-investment-myanmar.html

Luttwak, E. N. (1990). From geopolitics to geo-economics: logic of conflict, grammar of commerce. The National Interest, 20, 17-24. 
Leider, J. (2013). Rohingya: The name, the movement and the quest for identity. Myanmar Egress and the Myanmar Peace Center. pp. 204-255. Retrieved September 6, 2013, from http://www.burmalibrary.org/docs21/Jacques-P-Leider-2014-01-28-Rohingya-The_Name-The_movement-T he_quest_for_identity-en.pdf

Lanteigne, M. (2017). The rock that can't be moved': China's revised geostrategies in Myanmar. published at December 29; pp 37-55. https://doi.org/10.1080/09512748.2017.1419276

Maczka, K. B. (2010). De-securitizing East - Polish Discourse on Eastern Dimensions. University of Tempere, Department of Political Science and International Relations, International School of Social Science. Retrieved September 23, 2010, from https://trepo.tuni.fi/bitstream/handle/10024/81942/gradu04566.pdf?sequence=1\&isAllowed=y

Mattlin, M., \& Wigell, M. (2016). Geoeconomics in the context of restive regional powers. Asia Europe Journal, 14(2), 125-134. https://doi.org/10.1007/s10308-015-0443-9

Moshe, Y. (1972). Muslims of Burma. Wiesbaden: Verlag Otto Harrassowitz; pp. 96.

Moshe, Y. (1972). Muslims of Burma. Wiesbaden: Verlag Otto Harrassowitz; pp. 98-101.

Medeiros, S. E. (2009). China's International Behavior. https://doi.org/10.1016/S1567-7249(09)00104-4

Ministry of Foreign Affairs of the People's Republic of China. (2020). Wang Yi Holds Talks with State Counselor and Foreign Minister Aung San Suu Kyi of Myanmar. Retrieved October 1, 2020, from https://www.fmprc.gov.cn/mfa_eng/zxxx_662805/t1512574.shtml

McCarthy-Taraboulsi, S., Metcalfe-Hough, V., \& Willitis-King, B. (2016). Foreign policy and humanitarian action: an agenda for inquiry. HPG Working Paper; November. Retrieved September 29, 2016 from https://www.odi.org/sites/odi.org.uk/files/resource-documents/11125.pdf

Ministry of Foreign Affairs of the People's Republic of China. (2017). Speech by Foreign Minister Wang Yi at the Opening of Symposium on International Developments and China's Diplomacy in 2017. Retrieved September 24, 2017, from https://www.fmprc.gov.cn/mfa_eng/wjbxw/t1518130.shtml

Myanmar - Union Minister for Office of State Counselor Addresses General Debate, 73rd Session. (2018). You Tube Video; Added by UNGA [Online]. Retrieved from https://www.youtube.com/watch?reload=9\&v=fGW1QeGvNTU

Maskivker-Hernandez, G., Pamies, M. D. M., \& Valverde, M. (2018). Challenging Conventional Wisdom Positive Waiting. Retrieved September 28, 2018, from https://www.researchgate.net/publication/3228632

Myanmar Violence: UN unlikely to act against Myanmar military. (2017). You Tube Video; Added by TRT World. Retrieved from https://www.youtube.com/watch?v=a8UnNvKK3Ew

Myanmar: Aung San Suu Kyi exclusive interview - BBC News. (2017). Added by BBC News [Online]; Retrieved from https://www.youtube.com/watch?v=MFEEmdKbqBE

Majumder, S., Chopra, K., \& Chakraborty, M. (2015). Rohingyas in India - Birth of a Stateless Community; Mahanirban Calcutta Research Group; Salt Lake City, Calcutta. Retrieved September 13, 2015, from http://www.mcrg.ac.in/PP71.pdf

Newman, D., Murphy, A., Bassin, M., \& Agnew, J. (2004). Is There a Politics or Geopolitics; Progress in Human Geography; October. Retrieved October 3, 2004, from https://www.researchgate.net/publication/249871951

Okur, M. A. (n.d.). Classical Texts Of the Geopolitics and the "Heart Of Eurasia". Journal of Turkish World Studies, XIV(2), 76-90. Retrieved from https://www.academia.edu/10035574/CLASSICAL_TEXTS_OF_THE_GEOPOLITICS_AND_THE_HEA RT_OF_EURASIA_Jeopoliti\%C4\%9Fin_Klasik_Metinleri_ve_Avrasya_n\%C4\%B1n_Kalbi_http://tdid.eg e.edu.tr/files/dergi_14_2/mehmet_akif_okur.pdf

Pepe, E. (2001). Asia Times: Jihad - The Ultimate thermonuclear bomb.

Perwita, B. (2018). Sino-Myanmar Defense Corporation - China's effort to bolster its sphere of influence in the Indian Ocean. Stockholm International Peace Research Institute. Retrieved October 1, 2019 from https://www.researchgate.net/publication/329642717_SINO-MYANMAR_DEFENSE_COOPERATION_A ND_CHINA'S_EFFORTS_TO_BOLSTER_ITS_SPHERE_OF_INFLUENCE_IN_THE_INDIAN_OCEA N_2013-2017/link/5c1345e492851c39ebeb78b0/download

Patrick, B. (2012). The Kachin Borderland; Le Monde Diplomatique. 
Prothom, A. (2019). Is Bangladesh approaching towards a China 'debt trap'? Retrieved September 23, 2019, from https://en.prothomalo.com/bangladesh/news/198873/Is-Bangladesh-approaching-towards-a-China-debt

Rahman, Z. M., Anusara, J., Chanthamith, B., Hossain, S., \& Al-amin (2018). Rohingya Crisis - Identity of Rohingya Muslims in Myanmar. International Research Journal of Social Science, 7(12), 12-16. Retrieved September 11, 2018, from https://www.researchgate.net/publication/329987655

Ramachandran, S. (2017). Rohingya Crisis: Will China's Mediation Succeed? Jamestown Foundation, Rohingya Crisis: Will China's Mediation Succeed? China Brief, 17(1). Retrieved September 30, 2017, from https://www.refworld.org/docid/5a168ac04.html

Rohingya Crisis: China is very worried -- they have a lot to lose (2017) .You Tube Video; Added by France24 [Online]. Retrieved from https://www.youtube.com/watch? $=\mathrm{bXfhDYlp-Vg}$

Rech, M., Bos, D., Jenkings, N., Williams, A., \& Woodward, R. (2014). Geography, military geography, and critical military studies; 9th October [Online]; pp 47-60. https://doi.org/10.1080/233374866.2014.963416

Rysiew, P. (2003). Conventional Wisdom. $2^{\text {nd }}$ December; Willey Online Library. Retrieved September 28, 2003, from https://onlinelibrary.wiley.com/doi/abs/10.1111/1467-8284.00206

Shao, G. (2019). China, the world's second largest defense spender, becomes a major arms exporter. CNBC; $26^{\text {th }}$ September. Retrieved October 6, 2019, from

https://www.cnbc.com/2019/09/27/china-a-top-defense-spender-becomes-major-arms-exporter.html

Savic, B. (2017). China flexes its diplomatic muscle on the Rohingya crisis, cashing in on ties with Myanmar and Bangladesh; November; The Global Policy Institute. Retrieved from https://gpilondon.com/publications/china-flexes-its-diplomatic-muscle-on-the-rohingya-crisis-cashing-in-on -ties-with-myanmar-and-bangladesh

Song, L. (2018). Strengthening Responsibility Sharing with South-South Cooperation: China's Role in the Global Compact on Refugee. International Journal of Refugee Law, 30(4), 687-690. https://doi.org/10.1093/ijrl/eey059

Toncea, V. (2006). Geopolitical evolution of borders in Danube Basin.

Tishin, I. (1994). National Interest and Geopolitics: A primer on the Basic Provisions. Maxwell Airforce Base, Alabama. Retrieved September 16, 1994, from https://apps.dtic.mil/dtic/tr/fulltext/u2/a280767.pdf

Trading Economics. (2019). Myanmar Exports to China. Retrieved October 14, 2019, from https://tradingeconomics.com/myanmar/exports/china

UN. (2017). Secretary-General's remarks at open debate of the Security Council on Myanmar. Retrieved September 28, 2017, from

https://www.un.org/sg/en/content/sg/statement/2017-09-28/secretary-generals-remarks-open-debate-security -council-myanmar

UN (2015). Statement. by H.E. Xi Jinping President of the People's Republic of China At the General Debate of the 70th Session of the UN General Assembly, New York. Retrieved September 27, 2015, from https://gadebate.un.org/sites/default/files/gastatements/70/70_ZH_en.pdf

UNDP. (2018). Impact of the Rohingya Refugee Influx on Host Communities. Retrieved October 22, 2018, from https://www.undp.org/content/dam/bangladesh/docs/Publications/Pub-2019/Impacts\%20of\%20the\%20Rohi ngya\%20Refigee\%20Influx\%20on\%20Host\%20Communities.pdf

US Lawmakers: Ethnic Cleansing Taking Place in Myanmar. (2017). You Tube Video; Added by Voice of America News [Online]. Retrieved from https://www.youtube.com/watch?v=xC6G9CsCgxw

Voice of America. (2016). Rohingya Refugees Seek to Return Home to Myanmar.

With Rohingya gone, Myanmar remodels Rakhine state. (2018). You Tube Video; Added by Hindustan Times [Online]. Retrieved from https://www.youtube.com/watch? $v=5-1 \mathrm{czF0}$ sTFs

Womack, B. (2004). China and Southeast Asia: Asymmetry, Leadership and Normalcy. Pacific Affairs, 76(4), 529-548. Retrieved September 22, 2004, from https://www.jstor.org/stable/40026420

Wendt, A. (1999). A Social Theory of International Politics. https://doi.org/10.1017/CBO9780511612183

Yhome, K. (2019). Understanding China's response to ethnic conflicts in Myanmar; Observational Research Foundation - occasional paper; April, Vol: 188. Retrieved October 3, 2019, from 
https://www.orfonline.org/research/understanding-chinas-response-to-ethnic-conflicts-in-myanmar-49759/

Zhou, L. (2018). Sino-Myanmar defense co-operation and China's effort to bolster it's sphere in the Indian Ocean. Retrieved October 6, 2019, from https://www.researchgate.net/publication/329642717_SINO-MYANMAR_DEFENSE_COOPERATION_A ND_CHINA'S_EFFORTS_TO_BOLSTER_ITS_SPHERE_OF_INFLUENCE_IN_THE_INDIAN_OCEA N_2013-2017

Zalewski, J. (2017). Why China's three step approach won't be enough to solve the Rohingya crisis. Retrieved October 4, 2017, from

https://www.scmp.com/week-asia/opinion/article/2121497/why-chinas-three-step-approach-wont-be-enoug h-solve-rohingya

Zaman, S. (2014). China biggest arms supplier to Bangladesh. Dhaka tribune. Retrieved October 6, 2019, from https://www.dhakatribune.com/uncategorized/2014/03/17/china-biggest-arms-supplier-to-bangladesh

\section{Copyrights}

Copyright for this article is retained by the author(s), with first publication rights granted to the journal.

This is an open-access article distributed under the terms and conditions of the Creative Commons Attribution license (http://creativecommons.org/licenses/by/4.0/). 